\title{
Germination and Seedling Characters as Influenced by Sunflower Hybrids, Nitrogen Fertilizer Rates and Hill Spacing
}

\author{
Kandil A.A. ${ }^{1}$, A.E. Sharief $^{1}$, A.M.A. Odam ${ }^{2}$ \\ ${ }^{1}$ Agronomy Department, Faculty of Agriculture, Mansoura University, Egypt \\ ${ }^{2}$ Department of Seed science, Ministry of Agriculture, Egypt \\ Corresponding Author: Prof. Ali M. Sharief Mansoura University, Egypt, 35516 El-Mansoura, Egypt \\ Tel: +20122986347 Fax: +22221688 sharief2005@yahoo.com
}

\begin{abstract}
In order to study the performance of some sunflower genotypes to nitrogen fertilizer rates and plant population density to germination and seedling parameters. A laboratory experiment conducted in the Agronomy Department seed lab, Faculty of Agriculture, Mansoura University, Egypt during March and April 2017.The goals of this study aimed to study the effect of sunflower hybrids, nitrogen fertilizer rates and hill spacing on germination and seedling characters.The results indicated that Nsovak genotype recorded the highest values of abnormal seedling percentage. Highest mean germination time was obtained from MS.sirena F1 genotype. The highest coefficient of velocityand value of the vigour was produced from Biest Brima genotype without significant differences with sown Nsovak genotype.The results indicated that increasing nitrogen fertilizer rates from 72,120 and $168 \mathrm{~kg} \mathrm{~N} / \mathrm{ha}$ significantly increased mean germination timeandvalue of the vigour. The highest coefficient of velocity percentage produced from addition nitrogen fertilizer at $120 \mathrm{Kg} / \mathrm{ha}$. The results designated that increasing hill spacing from 15, 20 and $25 \mathrm{~cm}$ reduced germination percentage and mean germination time, however, significantly increased coefficient of velocity anddead seed percentages and value of the vigour.It could be concluded that sown Nsovak genotype at hill spacing of $15 \mathrm{~cm}$ and fertilizing with $120 \mathrm{~kg} \mathrm{~N} / \mathrm{ha}$ enhanced seed germination and viability.
\end{abstract}

Keywords - Sunflower cultivars, nitrogen fertilizer rates, Germination and seedling parameters.

\section{INTRODUCTION}

Sunflower (Helianthus annus L.) has higher seed and oil yieldsfrom the essential oilseed crop that gives a main share in edible oil production. It cultivated widely in the arid and semi-arid regions. In order to obtainseeds good in quality,so essential to getabetter plant stand. Sunflower Hybrids, nitrogen fertilizer levels and plant population density may affect germination parameters and seedling characters. In this respect, Sakha 53 exceeded Giza 102 in seed yield, its attributes and percentage of oil (Aml-ElSaiedy et al., 2011). The higher germination index, germination rate, number of days to $50 \%$ germination, germination index, root and shoot length and their dry weight produced from Urfloar cultivar as compared with Blazar cultivar(Moghanibashiet al., 2012). Line S 102 surpassed other studied cultivars in final germination percentage, germination rate and germination index, energy of germination and seedling vigor index(Kandil et al.,2016a).Sunflower differed from germination and seedling parameters, theLine S 102 outdone Sakha 53, Giza 102 and Line S 1 in the length of shoots, length of roots, weight of fresh and dry roots and weight of fresh and dry shoots(Kandil et al., 2016b).

Germination percentage and seed vigor did not affect by increasing applications of nitrogen fertilizer rates of 0,66 , 132 to $600 \mathrm{~kg} / \mathrm{ha}$ (Osechas and Torres 2002). Nitrogen fertilization in wheat enhanced of seed vigor and percentages of final germination and decreasedmean germination time and the time that $50 \%$ of the seeds germinated(Warraich, 2002). Seed viability, seedling vigour and cool germination test performance of cottonseed were all found to increase due to the addition of nitrogen fertilizer rate of $142.8 \mathrm{~kg} \mathrm{~N} / \mathrm{ha}$ (Zakaria, 2007). Environmental conditions affect seed quality of seed formation and affect seedling establishment of the next growing season (Zakaria, 2009). Fertilization of biological or artificial source as organic or inorganic material of nitrogen supplies nutrients essential to the soil and enhanced growth of plants (SSSA, 2011). The late in germination time was obtained from of Okapi cultivar by increasing nitrogen fertilizer levels. Planting cultivar of Zarfam and fertilizing with $100 \mathrm{~kg} / \mathrm{h}$ enhanced the amount of coefficient of speed of germination whichnitrogen fertilizer was applied of topdressing, however, the lowest amount was produced from sown 
Okapi cultivar without top dress of nitrogen fertilizer(Oskouie and Divsalar, 2011). Increasing nitrogen fertilizer increased seed yield for producing vigorous seeds (Wambugu et al, 2012).Nitrogen fertilization at a rate of $165 \mathrm{~kg} / \mathrm{ha}$ produced the highest percentages of seed germination and seedling vigor index. Maximum electrical conductivity related to seeds that received nitrogen fertilizer at a rate of $165 \mathrm{~kg} / \mathrm{ha}$. They concluded that uses of $165 \mathrm{~kg} / \mathrm{ha}$ nitrogen fertilizerson mother plants will produce seeds with higher vigor, germination characteristics and seedling establishment (Farhidi et al., 2014).Increasing nitrogen fertilizer rates in the mother plant field, genotypes and interaction of genotypes among nitrogen fertilizer influenced seed viability, germination, vigor of aromatic rice seeds (Hossain, 2014). Urea application produced the highest germination rate and followed by organic manure. Inorganic nitrogen fertilizer at Urea depicted maximum rate of shoot and root length. They suggested that urea is best fertilizer for germination of seedlings of sunflower and second one is FYM fertilizer (Shahzaman et al., 2017). Therefore, the purpose of this investigation aimed to study the effect of nitrogen fertilizer rates application for mother plants of sunflower cultivars and hill spacing on germination and vigor characters of resulted seed.

\section{MATERIALS AND METHODS}

\subsection{Research time and location:}

An experiment was conducted in the laboratory of seed science, Agronomy Department, Faculty of Agriculture Mansoura University Egypt during March and April 2017. The goals of this study was aimed to investigate the response of some sunflower cultivars (Giza102, Sakha 53, ) under three nitrogen rates $(72,120$ and $168 \mathrm{Kg} \mathrm{N} / \mathrm{ha}$ ) and three hills spacing $(15,20$ and $25 \mathrm{~cm}$ apart) to germination and seedling parameters.Afactorial experiment in Randomized Complete Block Design in four replication was used. The experiment includes three factors, the first sunflower genotypes (Nsovak, MS.Sirena F1, BiestBrima).The second factor included three nitrogen rates $(72,120$ and $168 \mathrm{Kg} \mathrm{N} / \mathrm{ha})$ and the third cultivar includesthree hills spacing $(15,20$ and $25 \mathrm{~cm}$ apart).Fifty seeds of uniform size in each treatment for each cultivar allowgerminating on Petri dishes in $9 \mathrm{~cm}$ diameter Petri dishes. Seeds were germinate in a germination chamber in $20-25^{\circ} \mathrm{C}$ (ISTA Rules, 2016). The experiment included 108 Petri dishes that moistened with a distilled water.

\subsection{Studied Characters:}

Sunflower seed of both seasons subjected for determination of the following characters:1-Average of final germination percentage (FGP): Seed germinated count taken after 14 days from sowing date and stated as a percentage affording to the following formula as defined by (Ellis and Roberts, 1981\& Ruan et al. 2002).

FGP $=\frac{\text { Number of germinated seeds }}{\text { Total Number of seed tested }} \times 100$

2-Percentage of abnormal seedling = Number of abnormal seedling/total number of seeds

3-The mean germination time (MGT): It was determined according to the equation of Ellis and Roberts (1981):

$$
\mathrm{MGT}=? \mathrm{dn} / \mathrm{n}
$$

4-Average of coefficient of velocity (CV) was calculated using the following formula as described by Scott et al., 1984:

$$
\mathrm{C} \mathrm{V}=100[? \mathrm{Ni} / ? \mathrm{Ni} \mathrm{Ti}]
$$

The $\mathrm{N}$ mean the number of germinated seeds on day $\mathrm{i}$ and $\mathrm{T}$ is mean that the number of days from sowing.

5 -Percentage of dead seed $=$ Number of dead seed /total number of seeds

6-The value of the vigour (V) was calculated as following formula according to Bradbeer 1988:

$$
\mathrm{V}=(\mathrm{a} / 1+\mathrm{b} / 2+\mathrm{c} / 3+\mathrm{d} / 4+\ldots+\mathrm{x} / \mathrm{n}) \times 100 / \mathrm{S}
$$

Where $a, b, c \ldots$ respectively represent the number of seeds which germinated after $1,2,3 \ldots$ days of imbibition, $x$ is the number of seed for day $\mathrm{n}$ and $\mathrm{S}$ the total number of seeds sown. The range of the $\mathrm{V}$ values is from 0 to 100 (maximum rate). The rates were categorized as five numbers categories: $0=$ Null; $1=$ Slow; $2=$ Medium; $3=$ Fast; and $4=$ Very fast was divided according to Mayer and Poljakoff, 1989. 


\subsection{Experimental analysis:}

The analysis of data collected done, statistically by the analysis of variance technique using the MSTAT-C statistical package programmed as described by a procedure of Gomez and Gomez (1991). For comparisons between treatment means, least significant differences test (LSD) at 0.05 level of probability was used according to Snedecor and Cochran (1980).

\section{RESULTS AND DISCUSSIONS}

3.1. Performance of sunflower cultivar on seed germination and seedling characters:

Averages of abnormal seedling percentages, mean germination time, coefficient of velocity,dead seed percentages and value of the vigour significantly affected by sunflower cultivars as shown in Tables 1 and 2, except germination and dead seed percentages insignificantly differed. The results indicated that Nsovak genotype recorded the highest values of abnormal seedling percentage $(6.67 \%)$. Highest mean germination time (2.53) was obtained from MS.sirena F1 genotype.The highest coefficient of velocity $(41.29 \%)$ and value of the vigour (42.19) were produced from Biest Brima genotype without significant differences with sown Nsovak genotype.The differences in final percentage of germination of seed may due to the amount of saved matters in endosperm and different seed size of genotypes. The processes that inhibit germination probably involve cell division and no transfer of nutrients (Bittman, 1989).Zarfam and Licord cultivars recorded the highest seed vigor (98\%) of both cultivars and Talaieh cultivar produced the lowest was(92\%)(Oskouie and Divsalar, 2011).

3.2. Effect of nitrogen fertilizer rates on seed germination and seedling characters:
Averages of mean germination time,coefficient of velocity andvalue of the vigoursignificantly affected by different nitrogen fertilizer rates, however insignificantly influencedgermination and abnormal seedling anddead seed percentages as shown in Tables 1 and 2 . The results indicated that increasing nitrogen fertilizer rates from 72 , 120 and $168 \mathrm{~kg} \mathrm{~N} / \mathrm{ha}$ significantly increased mean germination time (2.55) andvalue of the vigour (42.24). The highest coefficient of velocity percentage $(41.56 \%)$ produced from addition nitrogen fertilizer at $120 \mathrm{Kg} / \mathrm{ha}$. Seed lots with high vigor have lower mean germination time (Ellis and Robert, 1981). The lowest germination and vigour of seeds produced under conditions of lowsoil fertility (Songa et al., 1994). A fast and uniform field emergence is essential to do high yield with good quality and quantity of annual crops (Yari et al., 2010). The highest coefficient of speed of germination produced from nitrogen fertilization at a rate of $100 \mathrm{~kg}$ $\mathrm{N} / \mathrm{ha}$, for Zarfam cultivar and without nitrogen fertilization for Okapi cultivar produced the lowermost coefficient of speed germination (Oskouie and Divsalar, 2011).

3.3. Effect of hill spacing on seed germination and seedling characters:

Means of germination and abnormal seedling percentages and average of germination time, percentages of coefficient of velocity anddead seed as well as value of the vigour significantly affected by plant hill spacing as shown in Tables 1 and 2. The results designated that increasing hill spacing from 15,20 and $25 \mathrm{~cm}$ reduced germination percentage $(96.53 \%)$ and mean germination time (2.41), however, significantly increased coefficient of velocity $(41.54 \%)$ anddead seed $(3.55 \%)$ percentages and value of the vigour (42.40). 
Table.1: Average of germination and abnormal seedling percentages and mean germination time as affected by sunflower cultivars, nitrogen fertilization and hill spacing.

\begin{tabular}{|c|c|c|c|}
\hline$\underbrace{\text { Characters }}_{\text {Treatment }}$ & $\begin{array}{c}\text { Germination } \\
\%\end{array}$ & Abnormal Seedling \% & $\begin{array}{l}\text { Mean germination } \\
\text { time }\end{array}$ \\
\hline \multicolumn{4}{|c|}{ A-Sunflower cultivars: } \\
\hline Nsovak & 96.96 & 6.67 & 2.43 \\
\hline MS.sirena F1 & 97.63 & 5.33 & 2.53 \\
\hline Biest Brima & 97.18 & 5.04 & 2.40 \\
\hline F. test & NS & $*$ & $*$ \\
\hline LSD at $5 \%$ & -- & 1.03 & 0.03 \\
\hline \multicolumn{4}{|c|}{ B-Nitrogen fertilization } \\
\hline 72 kg N/ha & 97.85 & 5033 & 2.43 \\
\hline $120 \mathrm{~kg} \mathrm{~N} / \mathrm{ha}$ & 97.33 & 5.48 & 2.41 \\
\hline $168 \mathrm{~kg} \mathrm{~N} / \mathrm{ha}$ & 96.59 & 6.22 & 2.55 \\
\hline F. test & NS & NS & $*$ \\
\hline LSD at $5 \%$ & -- & -- & 0.03 \\
\hline \multicolumn{4}{|l|}{ C-Hill spacing: } \\
\hline $15 \mathrm{~cm}$ apart & 98.14 & 3.70 & 2.55 \\
\hline $20 \mathrm{~cm}$ apart & 97.11 & 6.07 & 2.43 \\
\hline $25 \mathrm{~cm}$ apart & 96.52 & 7.26 & 2.41 \\
\hline F. test & $*$ & $*$ & $*$ \\
\hline LSD at $5 \%$ & 1.13 & 1.18 & 0.05 \\
\hline \multicolumn{4}{|l|}{ D-Interaction F- test: } \\
\hline $\mathrm{A} \times \mathrm{B}$ & NS & $*$ & $*$ \\
\hline $\mathrm{A} \times \mathrm{C}$ & $*$ & $*$ & $*$ \\
\hline $\mathrm{B} \times \mathrm{C}$ & $*$ & $*$ & NS \\
\hline $\mathrm{A} \times \mathrm{B} \times \mathrm{C}$ & NS & NS & NS \\
\hline
\end{tabular}

\subsection{Interaction Effects:}

\subsubsection{Interaction between cultivars and nitrogen} fertilizer rates:

Averages of abnormal seedling percentage, mean germination time, coefficient of velocitypercentage and value of the vigour significantly influenced by the interaction between sunflower cultivars and nitrogen fertilization, however, germination and dead seed percentages insignificantly affected as shown in Tables 1 and 2. The results graphically illustrated in Figs. 1 and 2 clearly showed that the effect of the interaction between sunflower cultivars and nitrogen fertilization on abnormal seedling percentage and mean germination time. The highest percentages of abnormal seedling (7.11) and mean germination time $(2.49,2.70)$ were obtained from sown Nsovak orMS.sirena F1 genotypes when increasing nitrogen fertilizer up to $168 \mathrm{~kg} \mathrm{~N} / \mathrm{ha}$, respectively. The highest coefficient of velocitypercentage $(42.41 \%)$ produced from the interaction of planting Biest Brima genotype that fertilized with $72 \mathrm{~kg} \mathrm{~N} / \mathrm{ha}$ as graphically demonstrated in Figs 3. The highest values of value of the vigour(42.86) was recorded from the interaction of planting MS.sirena F1 genotype that fertilized with 120 $\mathrm{kg} \mathrm{N} / \mathrm{ha}$ as graphically demonstrated in Figs 4.Supply of different fertilizer rates in the mother plant field, cultivar and the interaction of cultivar and fertilizer much affected seed germination of vigor of aromatic rice seeds(Hossain, 2014). 
Table.2:.Average of coefficient of velocityanddead seedpercentages andvalue of the vigour as affected by sunflower cultivars, nitrogen fertilization and hill spacing.

\begin{tabular}{|c|c|c|c|}
\hline $\begin{array}{l}\text { Characters } \\
\text { Treatments }\end{array}$ & $\begin{array}{l}\text { Coefficient of } \\
\text { velocity } \%\end{array}$ & $\begin{array}{c}\text { Dead seed } \\
\%\end{array}$ & Value of the vigour \\
\hline \multicolumn{4}{|c|}{ A-Sunflower cultivars: } \\
\hline Nsovak & 41.16 & 3.26 & 41.53 \\
\hline MS.sirena F1 & 39.67 & 2.37 & 40.82 \\
\hline Biest Brima & 41.29 & 2.82 & 42.19 \\
\hline F. test & $*$ & NS & $*$ \\
\hline LSD at $5 \%$ & 0.42 & -- & 0.62 \\
\hline \multicolumn{4}{|c|}{ B-Nitrogen fertilization } \\
\hline $72 \mathrm{~kg} \mathrm{~N} / \mathrm{ha}$ & 41.15 & 2.37 & 41.97 \\
\hline $120 \mathrm{~kg} \mathrm{~N} / \mathrm{ha}$ & 41.56 & 2.67 & 40.33 \\
\hline $168 \mathrm{~kg} \mathrm{~N} / \mathrm{ha}$ & 39.42 & 3.41 & 42.24 \\
\hline F. test & $*$ & NS & $*$ \\
\hline LSD at $5 \%$ & 0.42 & -- & 0.62 \\
\hline \multicolumn{4}{|l|}{ C-Hill spacing: } \\
\hline $15 \mathrm{~cm}$ apart & 39.32 & 2.07 & 40.78 \\
\hline $20 \mathrm{~cm}$ apart & 41.26 & 2.81 & 41.35 \\
\hline $25 \mathrm{~cm}$ apart & 41.54 & 3.55 & 42.40 \\
\hline F. test & $*$ & $*$ & $*$ \\
\hline LSD at $5 \%$ & 0.70 & 1.13 & 0.51 \\
\hline \multicolumn{4}{|l|}{ D-Interaction F- test: } \\
\hline $\mathrm{A} \times \mathrm{B}$ & $*$ & $\mathrm{NS}$ & $*$ \\
\hline $\mathrm{A} \times \mathrm{C}$ & $*$ & NS & $*$ \\
\hline $\mathrm{B} \times \mathrm{C}$ & NS & $*$ & $*$ \\
\hline $\mathrm{A} \times \mathrm{B} \times \mathrm{C}$ & $\mathrm{NS}$ & $\mathrm{NS}$ & NS \\
\hline
\end{tabular}

\subsubsection{Interaction between cultivars and hill spacing:}

Averages of germination and abnormal seedling percentage, mean germination time, coefficient of velocitypercentage and value of the vigour significantly influenced by the interaction amonggenotypes and hill spacing, however, dead seed percentages insignificantly affected as shown in Tables 1 and 2.The results graphically illustrated in Figs. 5, 8 and 9 clearly showed that the highest germination percentage of $(98.67$ $\%)$,coefficient of velocitypercentage $(42.90 \%)$ and value of the vigour (42.33) were obtained from sown Biest Brima genotype when sown at dense hill spacing of 25 $\mathrm{cm}$, respectively.The highest abnormal seedling percentage $(9.48 \%)$ was produced from the interaction of planting MS.sirena F1 genotype when sown at wider hill spacing of $20 \mathrm{~cm}$ as graphically demonstrated in Figs 6.The highest mean germination time (2.72) was produced from the interaction of planting MS.sirena F1 genotype when sown at dense hill spacing of $15 \mathrm{~cm}$ as graphically demonstrated in Figs 7.

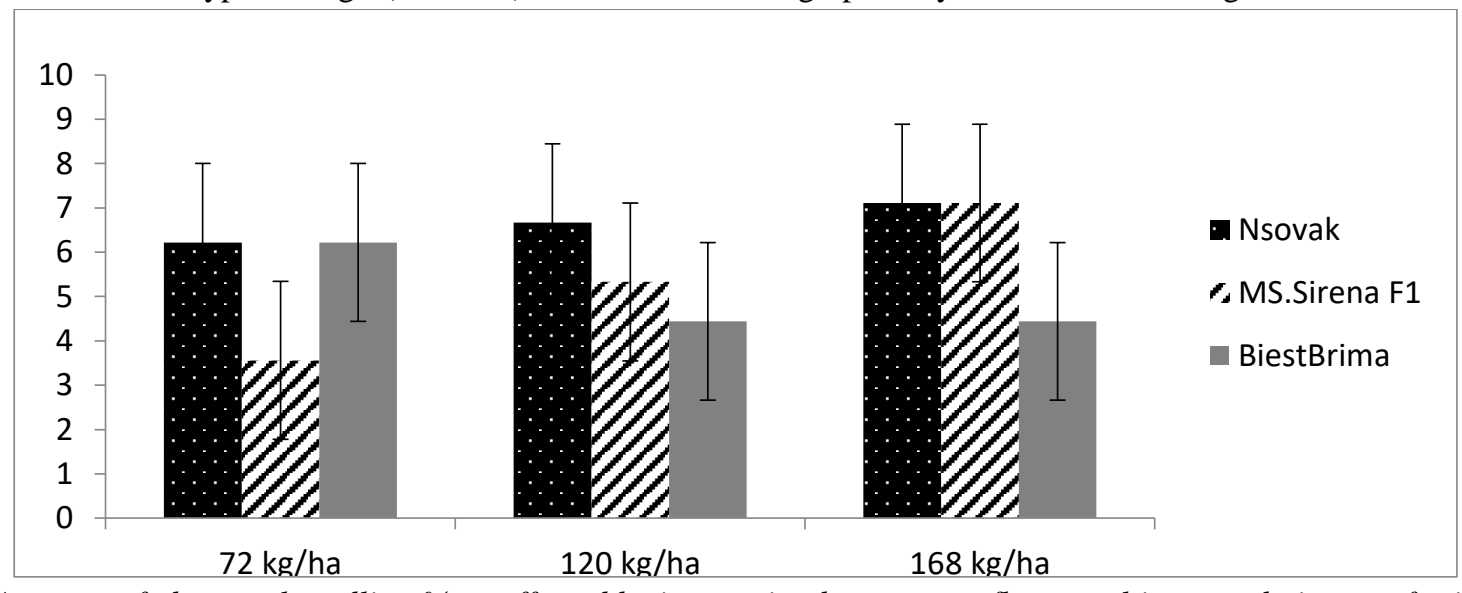

Fig.1: Average of abnormal seedling \% as affected by interaction between sunflower cultivars and nitrogen fertilization. 


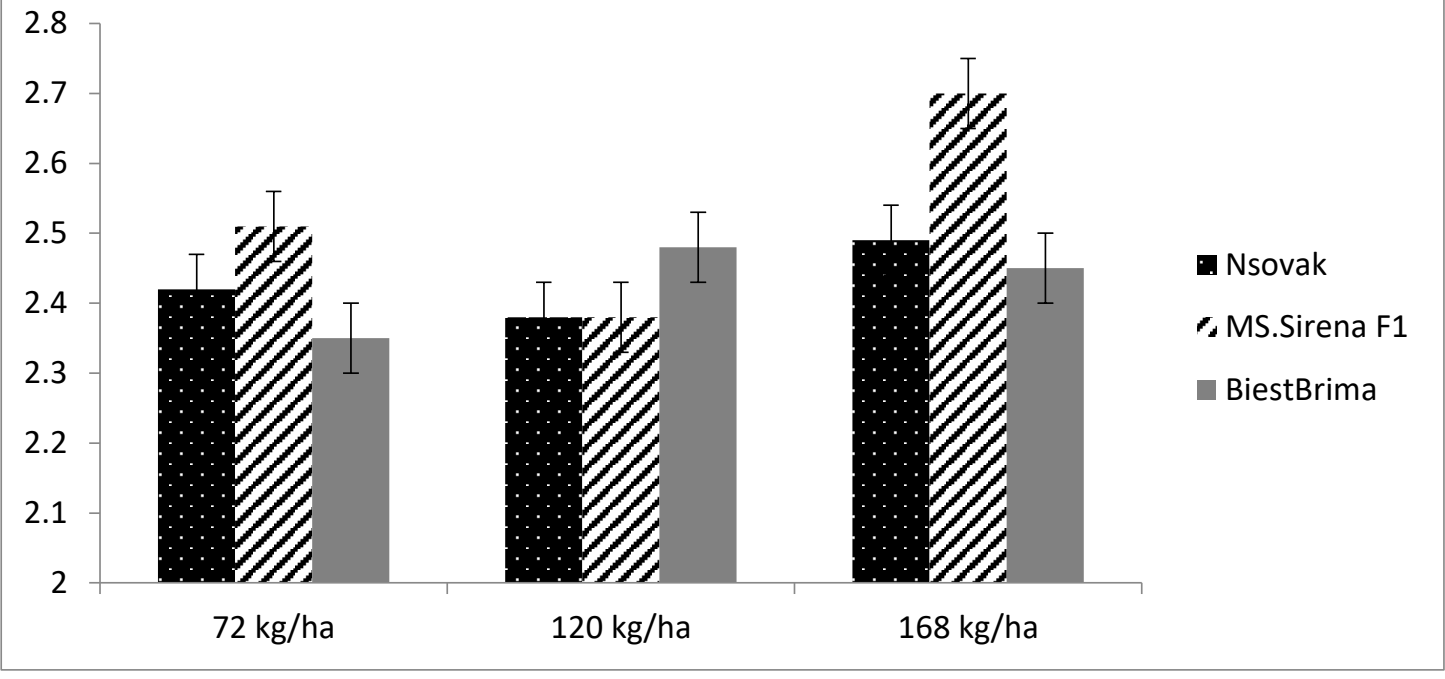

Fig.2: Average of mean germination time as affected by interaction between sunflower cultivars and nitrogen fertilization rates.

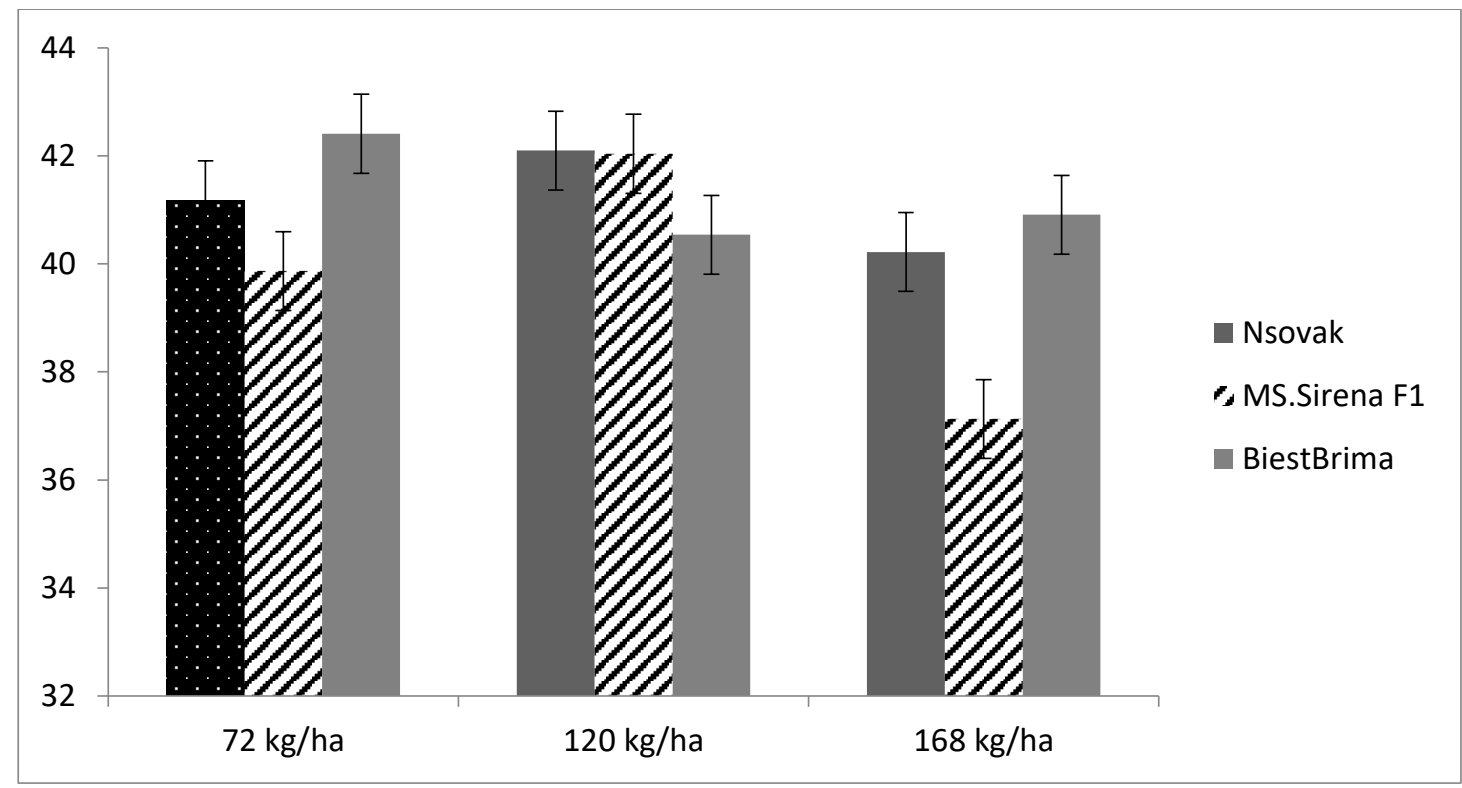

Fig.3: Average of coefficient of velocitypercentage as affected by interaction between sunflower cultivars and nitrogen fertilization rates.

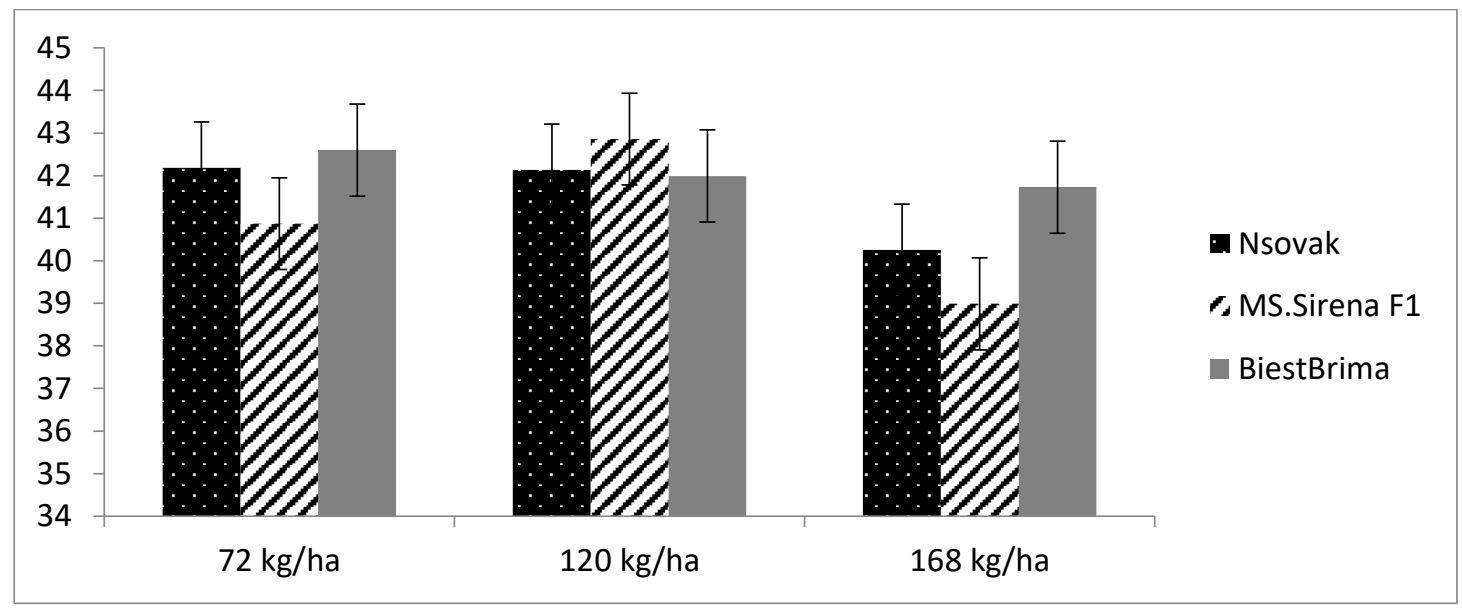

Fig.4: Average of value of the vigour as affected by interaction between sunflower cultivars and nitrogen fertilization rates. 


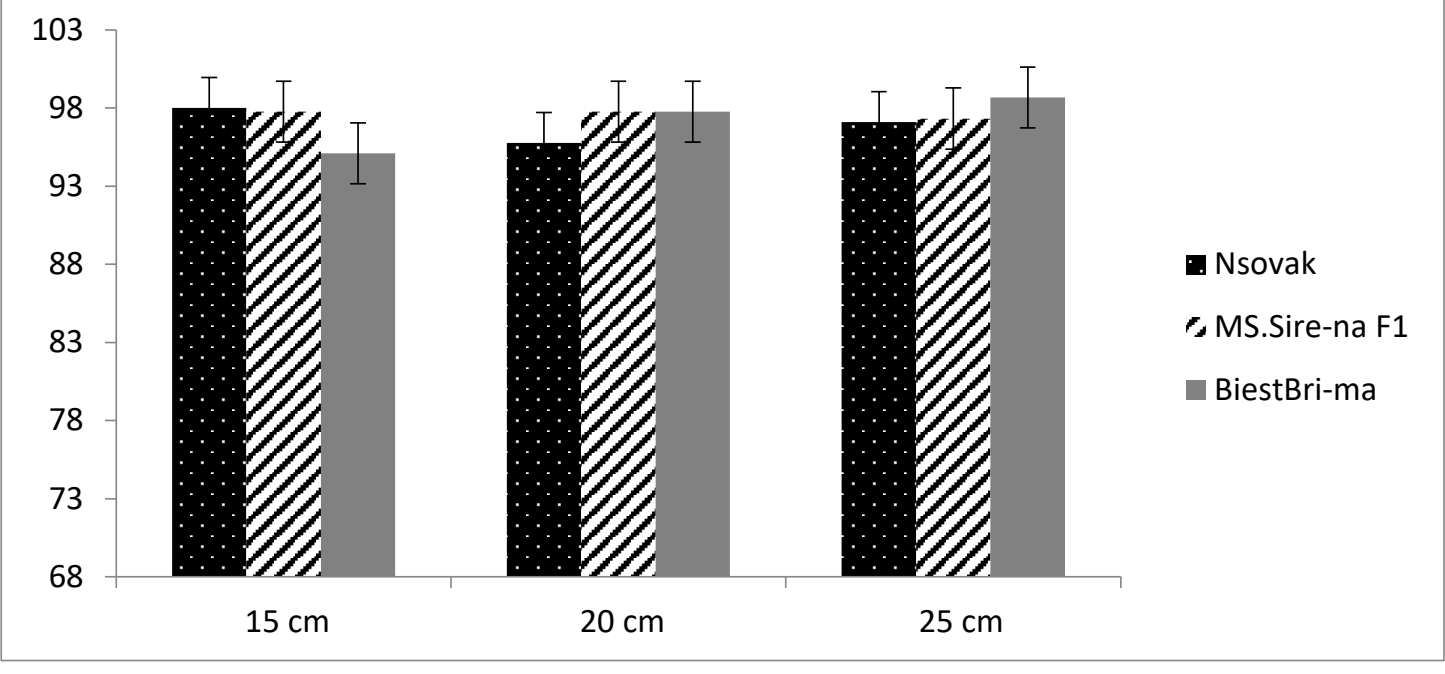

Fig.5: Average of germination percentage as affected by interaction between sunflower cultivars and plant density.

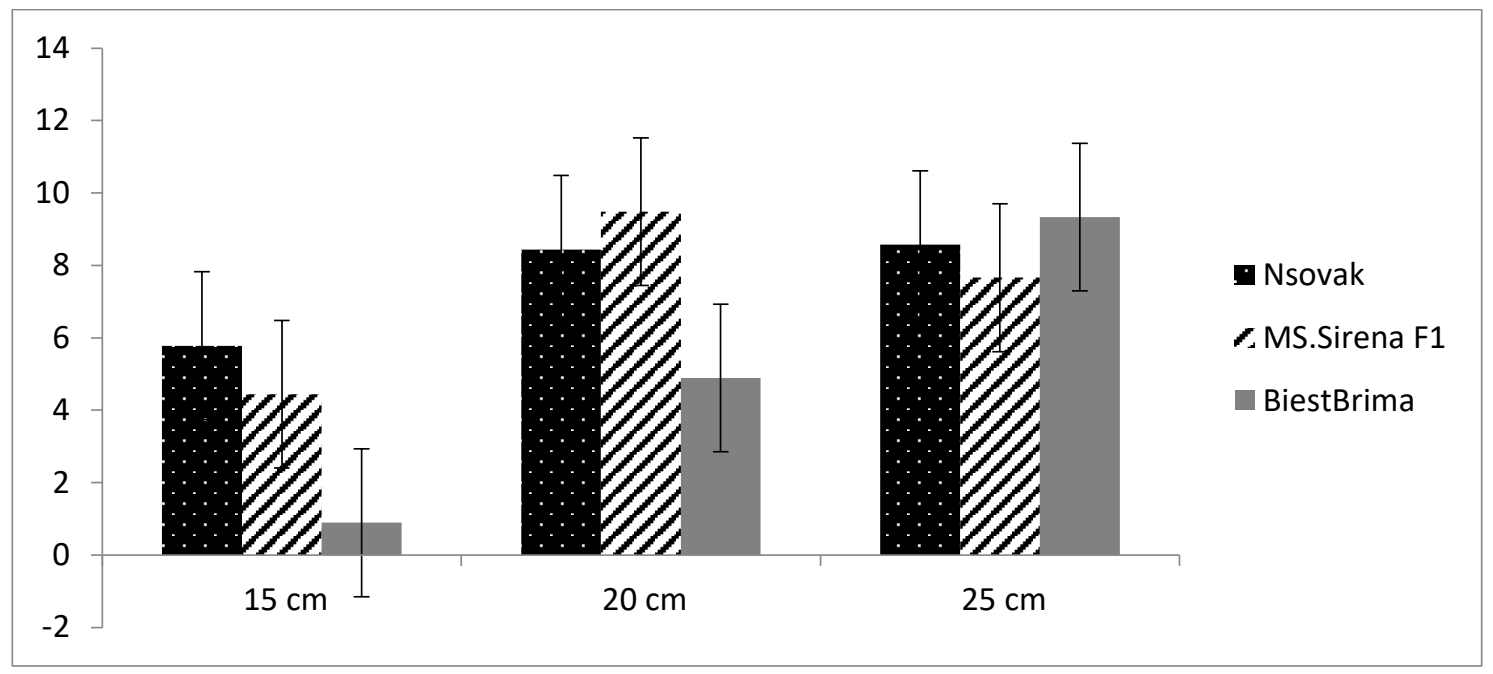

Fig.6: Average of abnormal seedling \% as affected by interaction between sunflower cultivars and hill spacing.

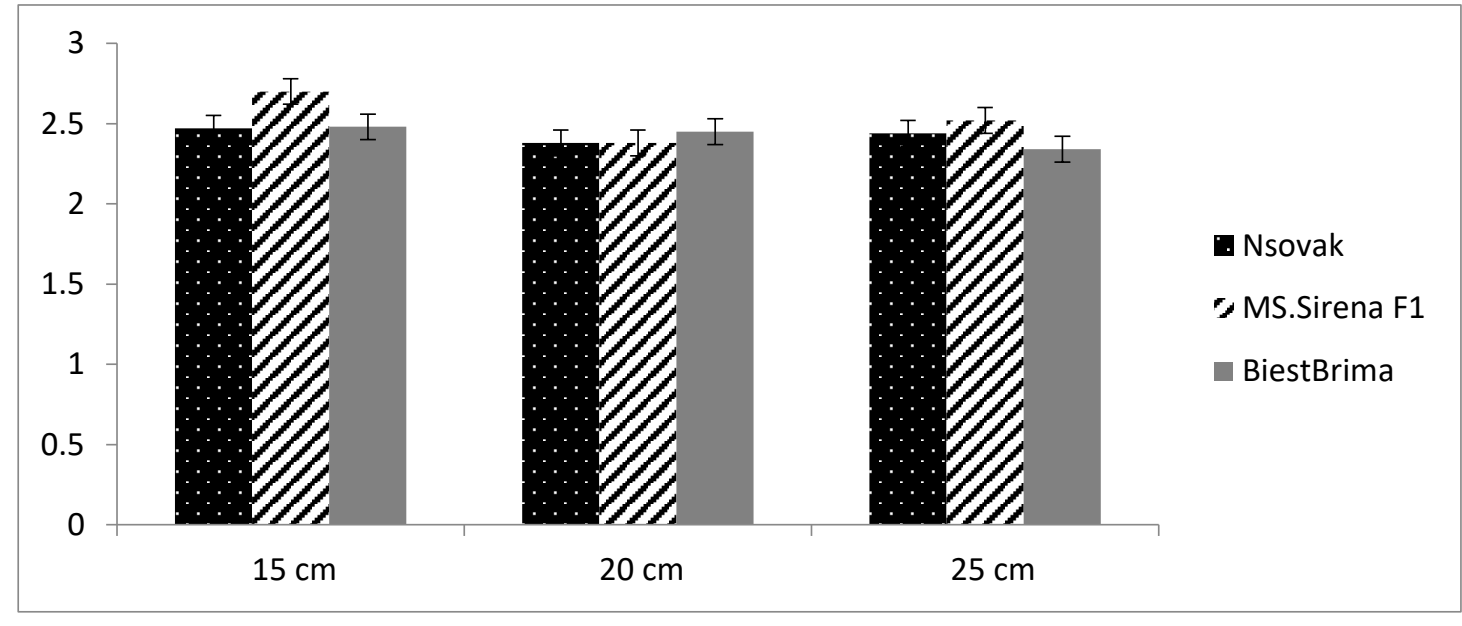

Fig.7: Average of mean germination time as affected by interaction between sunflower cultivars and hill spacing. 


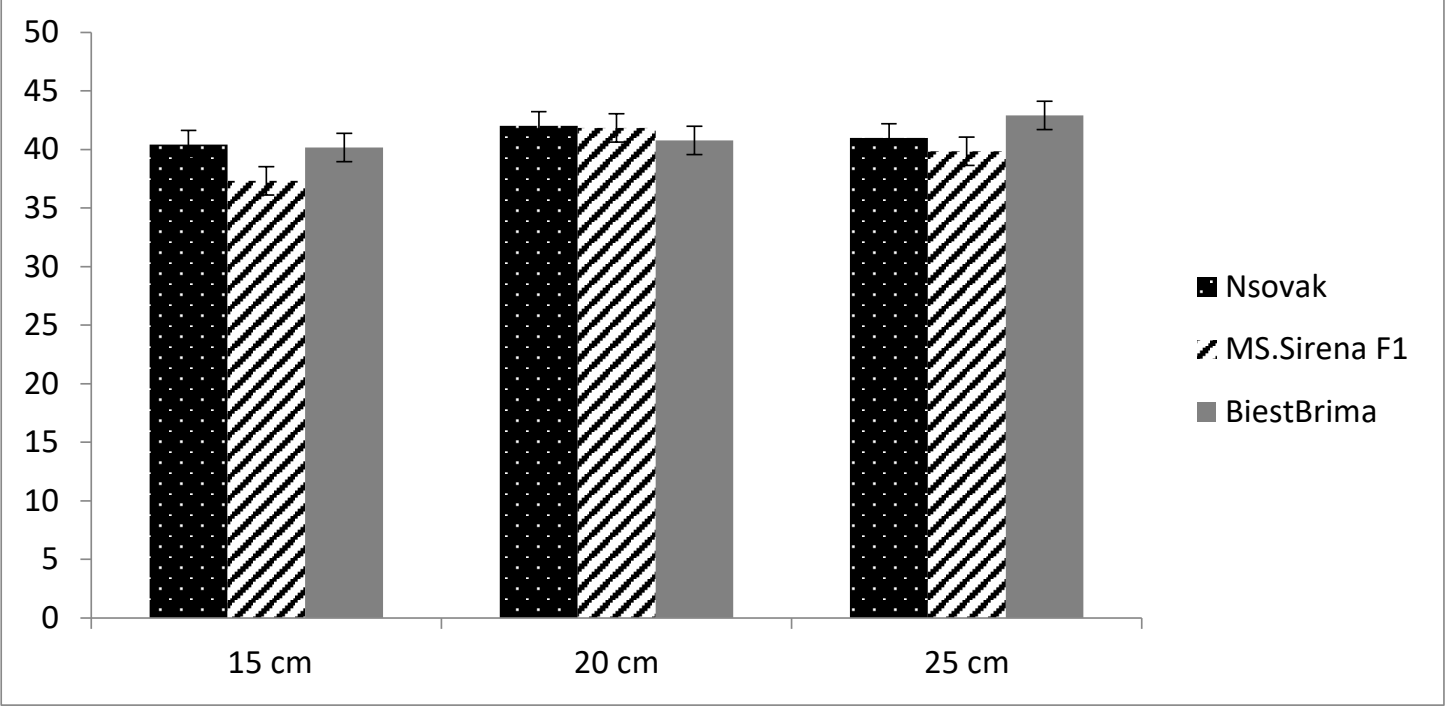

Fig. 8: Average of C.V\% as affected by interaction between sunflower cultivars and hill spacing.

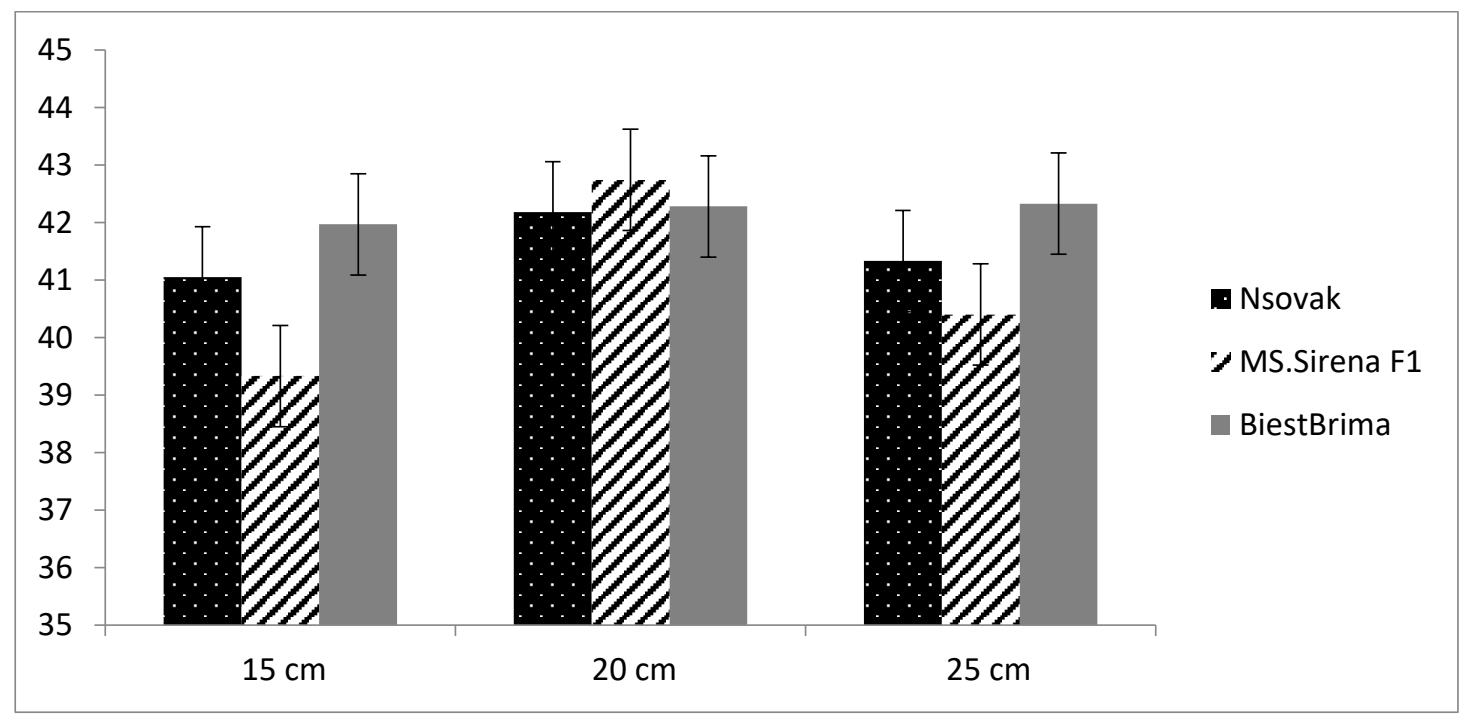

Fig.9: Average of value of the vigour as affected by interaction between sunflower cultivars and hill spacing.

\subsubsection{Interaction between nitrogen fertilizer rates and hill spacing:}

Averages of germination, abnormal seedling, dead seed percentages and value of the vigour significantly affected by the interaction between nitrogen fertilizer rates and hill spacing, however, mean germination time and coefficient of velocity percentage insignificantly affected as shown in Tables 1 and 2.The results graphically illustrated in Figs. 10 clearly showed that the effect of the interaction between nitrogen fertilizer rates and hill spacing on germination percentage, the results showed that the highest germination percentage $(100 \%)$ was obtained from sown sunflower fertilized with $120 \mathrm{~kg} \mathrm{~N} / \mathrm{ha}$ and sown at hill spaces of $15 \mathrm{~cm}$. The highest abnormal seedling percentage $(9.78 \%)$ was recorded from fertilization with $120 \mathrm{~kg} \mathrm{~N} / \mathrm{ha}$ and sown at wider hill spacing of $25 \mathrm{~cm}$ as graphically demonstrated in Figs 11. The highest dead seed percentages percentage (4.89\%) $\mathrm{w}+$ as produced from fertilization with nitrogen at rate of $120 \mathrm{~kg} \mathrm{~N} /$ ha when sown at wider hill spacing of $25 \mathrm{~cm}$ as graphically demonstrated in Figs 12.The highest values of value of the vigour(43.26) was produced from fertilization with nitrogen at rate of $120 \mathrm{~kg} \mathrm{~N} / \mathrm{ha}$ when sown at hill spacing of $20 \mathrm{~cm}$ as graphically demonstrated in Figs 13. 


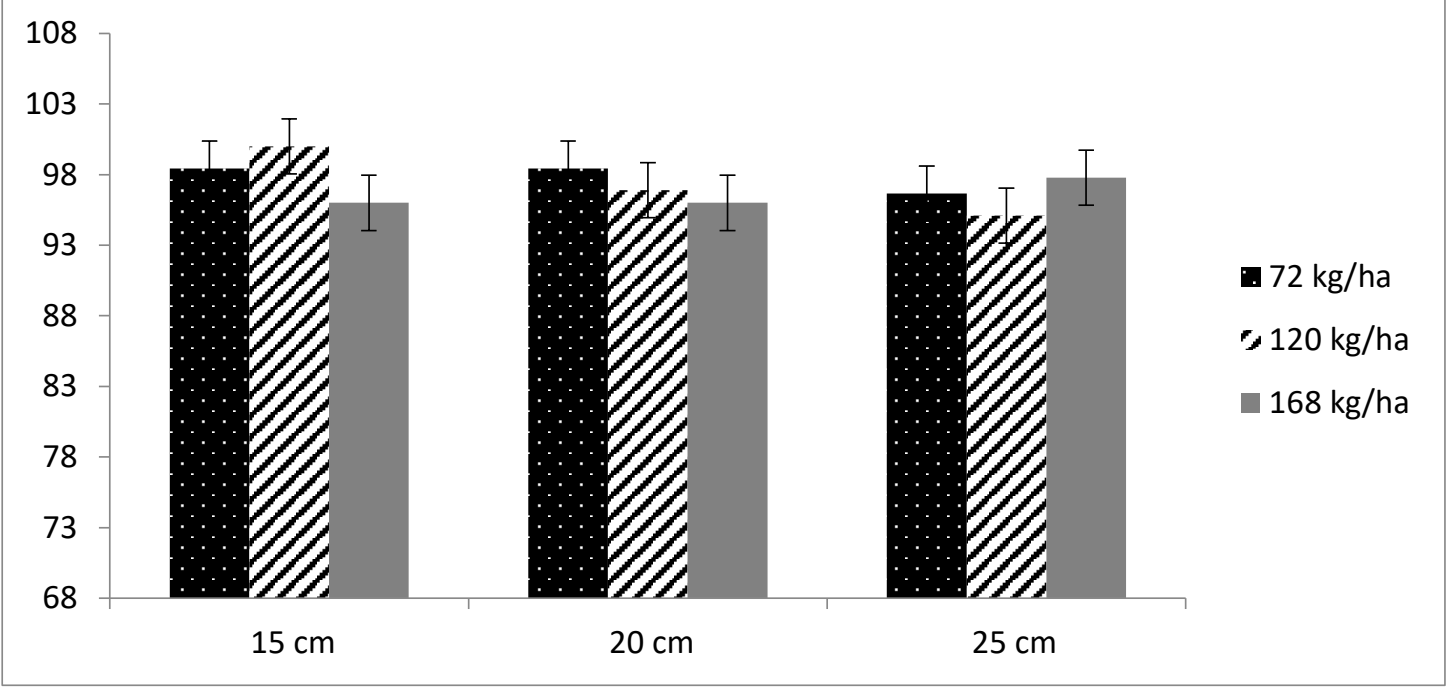

Fig.10: Average of germination percentage as affected by interaction between nitrogen fertilization and plant density

velocityand dead seed percentages and value of the vigour insignificantly affected by the interaction between sunflower cultivars $\mathrm{x}$ nitrogen fertilizer rates $\mathrm{x}$ hill spacing as shown in Tables 1 and 2.
3.4.4. Interaction between cultivars, nitrogen fertilizer rates, and hill spacing:

Averages of germination and abnormal seedling percentage, mean germination time, coefficient of

\section{CONCLUSION}

Accordingly, it could be summarized that sown Nsovak genotype at hill spacing of $15 \mathrm{~cm}$ and fertilizing with $120 \mathrm{~kg} \mathrm{~N} / \mathrm{ha}$ enhanced seed germination and viability.

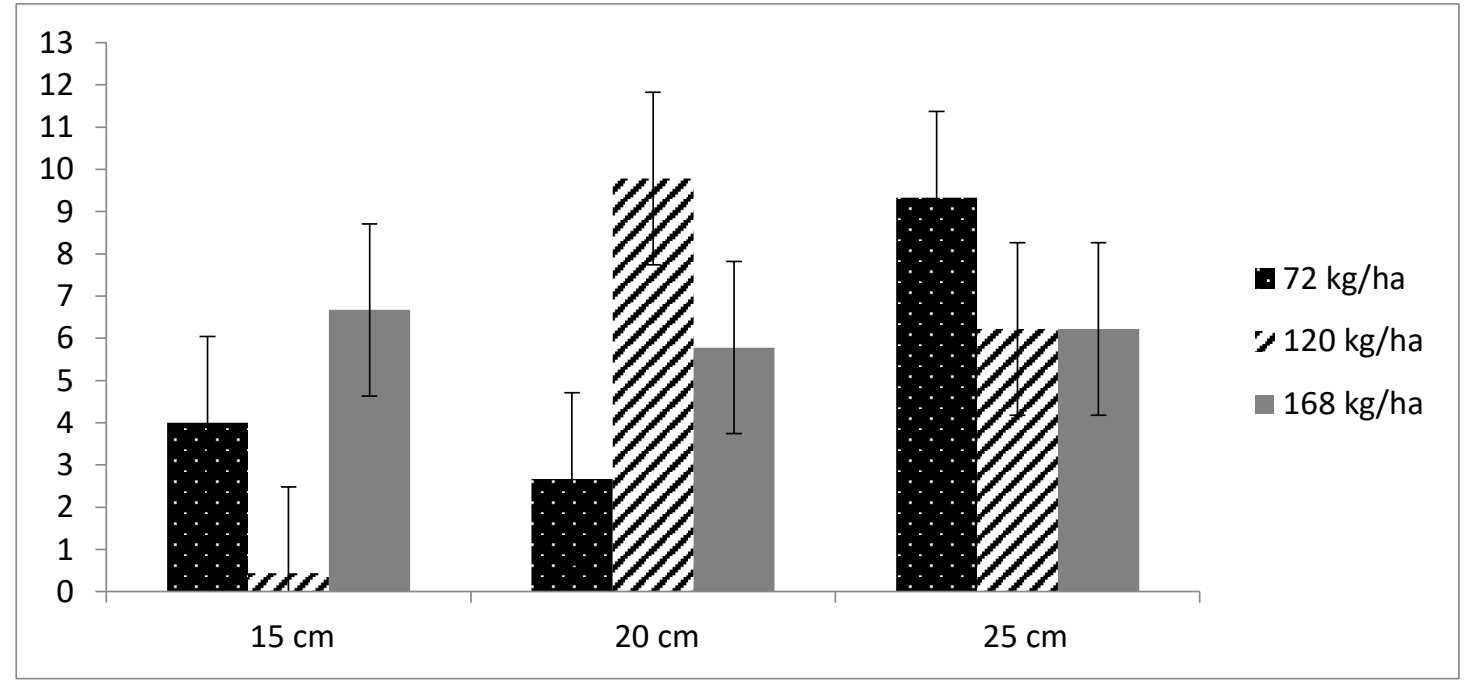

Fig.11: Average of abnormal seedling \% as affected by interaction between nitrogen fertilization and hill spacing. 


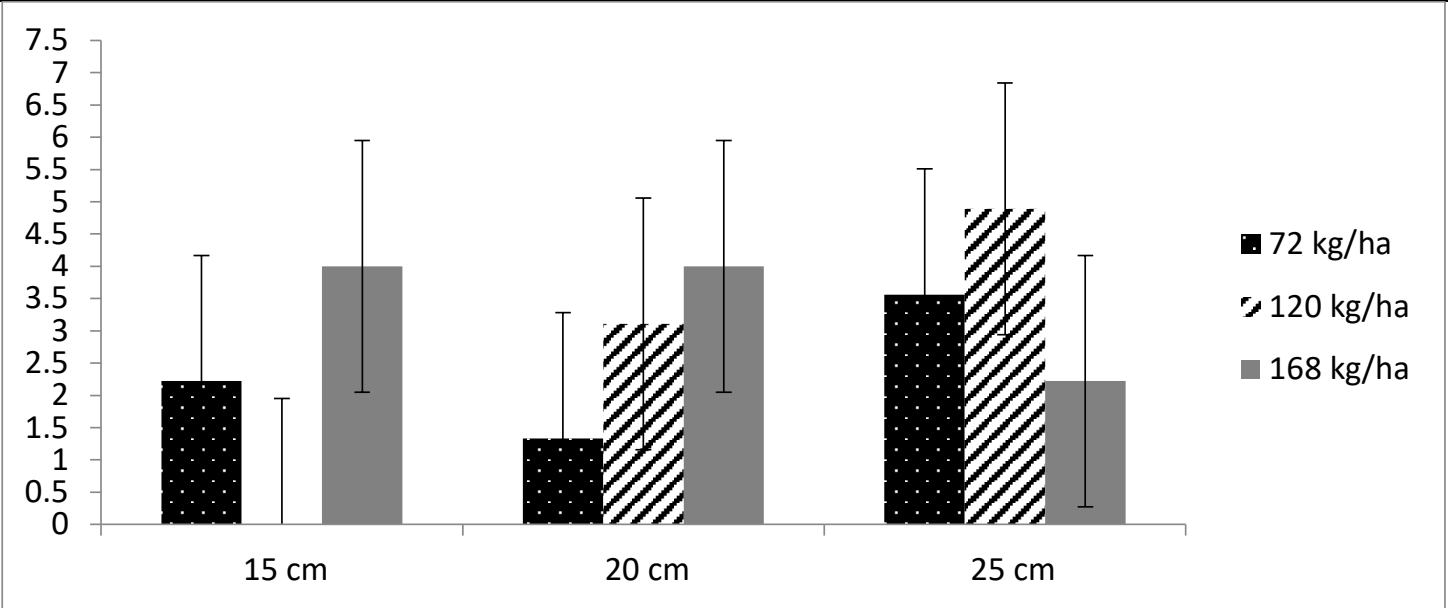

Fig.12: Average of dead seed\% as affected by interaction between nitrogen fertilization and plant density.

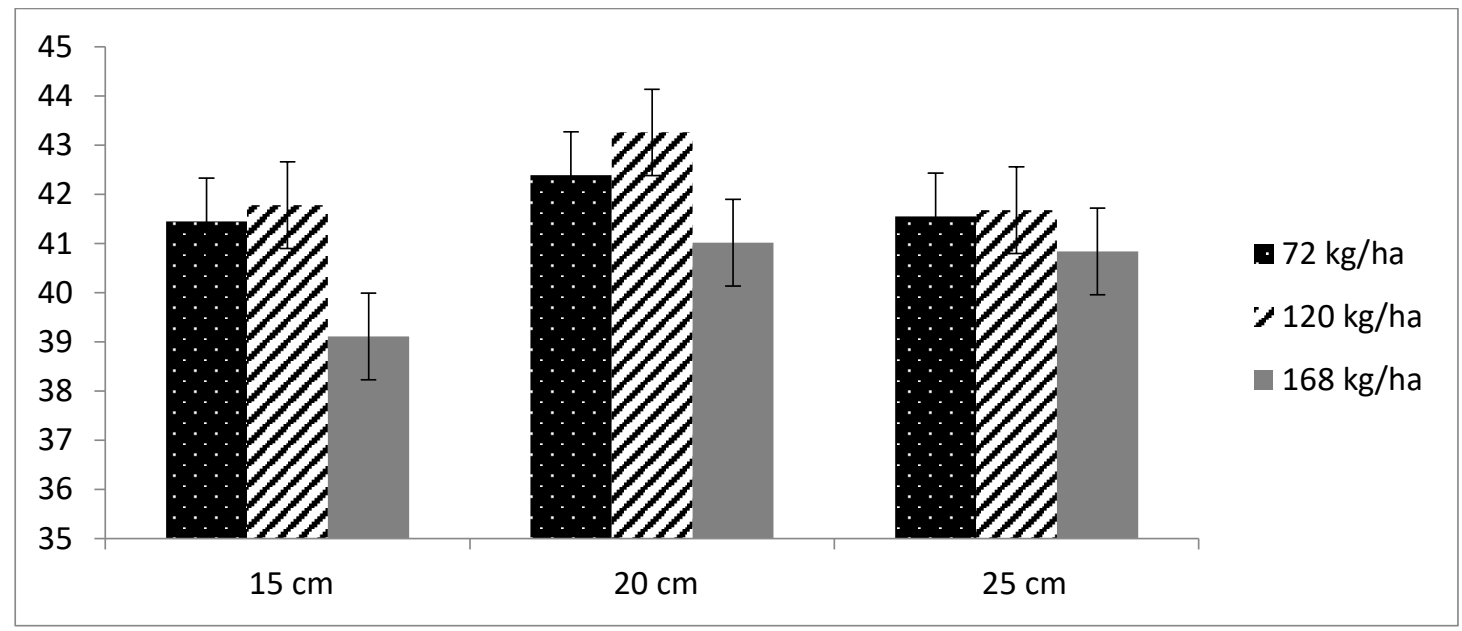

Fig.13: Average of value of the vigour as affected by interaction between nitrogen fertilization and plant den nitrogen fertilization and plant density during two season (A) 2014 and (B)2015.

\section{REFERENCES}

[1] Abdel-Baki, A. A. and J. D. Anderson 1973.Viability and leaching of sugars from germinating barley. Crops Sci., 10: $31 \quad-$ 34.https://dl.sciencesocieties.org/publications/cs/abst racts/10/1/CS0100010031

[2] Aml, E.A. El-Saidy, S. Farouk and H.M. Abd ElGhany 2011. Evaluation of Different Seed Priming on Seedling Growth, Yield and Quality Components in Two Sunflower (Helianthus annuus L.) Cultivars. Trends in Applied Sciences Research, 6: 977991.http://scialert.net/fulltext/?doi=tasr.2011.977.99 1 \&org $=10$

[3] Bittman, S. and G.M. Simpsan 1989. Drought effect on water relation of tree cultivated grasses. Crop Sci., 29: 992-999. Carter, J.E. and Paterson, R.P. 1985. Use of relative water content as a seclusion tool for drought tolerance. In: Agron Abs ASA.
[4] Bradbeer J. W., 1988. Seed Dormancy and Germination.- Chapman \& Hall, New York.

[5] Ellis, R.A. and E.H. Roberts 1981. The quantification of ageing and survival in orthodox seeds. Seed Sci. Technol., 9: 373409.http://agris.fao.org/agrissearch/search.do?recordID $=$ XE8182678

[6] Farhadi, E., J Daneshyan, A Hamidi, AH Shirani Rad and H.R. Valadabadi 2014. Effects of parent plant nutrition with different amounts of nitrogen and irrigation on seed vigor and some characteristics associated with hybrid 704 in Kermanshah region. Journal of Novel Applied Sciences, 3(5): 551556.http://jnasci.org/wpcontent/uploads/2014/05/551-556.pdf

[7] Gomez, K.A. and A.A. Gomez 1991.Statistical Procedures in Agricultural Research, John Wiley and Sons, New York. http://pdf.usaid.gov/pdf_docs/PNAAR208.pdf 
[8] Hossain, M. F. 2014. Impact of Fertilizers on the Seed Quality of Aromatic Rice. Journal of Agricultural Science, 6 (6): 3540.http://www.ccsenet.org/journal/index.php/jas/arti cle/viewFile/31803/20680

[9] Islam, M.M. and M. A. Karim 2010. Evaluation of Rice Oryza sativa L. genotypes at germination and early seedling stage for their tolerance to salinity. The Agric., 8 (2): $57 \quad-65$. http://www.banglajol.info/index.php/AGRIC/article/ view/7578

[10] ISTA Rules 2016.International seed testing association. ISTA Germination Sec. Chapter 19: pp. $19-41$.

https://www.seedtest.org/upload/cms/user/OGM1505-Proposed-Changes-to-the-ISTA-Rules-for2016.pdf

[11] Karim, M.A., N. Utsunomiya and S. Shigenaga 1992. Effect of sodium chloride on germination and growth of hexaploid triticale at early seedling stage. Japanese Journal of Crop Science,61: 279 - 284. https://www.jstage.jst.go.jp/article/jcs1927/61/2/61_ 2_279/_article

[12] Kandil, A. A. and A. E. Sharief and Amira A. Mamoon 2016a. Germination characters as affected by seed priming of some sunflower cultivars under salinity stress. International Journal of Agronomy and Agricultural Research (IJAAR)., 9(2):100116.http://www.innspub.net/wpcontent/uploads/2016/08/IJAAR-V9No2-p100116.pdf

[13] Kandil, A. A. and A. E. Sharief and Amira A. Mamoon 2016b. Seedling parameters of some sunflower cultivars as affected by seed priming and salinity stress. International Journal of Agronomy and Agricultural Research (IJAAR)., 9(2):117136.http://www.innspub.net/ijaar/seedlingparameters-of-some-sunflower-cultivars-as-affectedby-seed-priming-and-salinity-stress/

[14] Karim MA, N. Utsunomiya and S. Shigenaga 1992. Effect of sodium chloride on germination and growth of hexaploid triticale at early seedling stage. Japanese J. of Crop Sci.,61: 279 - 284. https://www.jstage.jst.go.jp/article/jcs1927/61/2/61_ 2_279/_article

[15] Mayer, A.M. and M. A. Poljakoff 1989. The germination of seeds4th ed . Pergamon Press, Oxford.

[16] Moghanibashi, M., H. Karimmojeni, P. Nikneshan and D. Behrozi 2012. Effect of hydro priming on seed germination indices of sunflower (Helianthus annuus L.) under salt and drought conditions. Plant Knowledge Journal, $1(1)$ : 10- 15.http://www.sciencej.com/karimojani_1_1_2012_ 10_15.pdf

[17] Osechas D, Torres A and Becerra L. 2002. Effect of nitrogen fertilization on the production and quality of seed of signal grass (Urochloadecumbens, Stapf). Zootecnica Tropical, 20(1): 135143.http://www.bioline.org.br/request?zt02010

[18] Oskouie, B. and M. Divsalar 2011. The effect of Mother Plant Nitrogen on Seed Vigor and Germination in Rapeseed. ARPN Journal of Agricultural and Biological Science, 5(5): 4956.http://www.arpnjournals.com/jabs/research_pape rs/rp_2011/jabs_0511_275.pdf

[19]Ruan, S., Q, Xue and K. Tylkowska 2002. Effects of seed priming on germination and health of rice Oryza sativa L. seeds. Seed Science and Technology, 30: 451-458. http://www.uaiasi.ro/CERCET_AGROMOLD/CA315-05.pdf

[20] Russell, D.F. 1986.MSTAT-C computer based data analysis software Crop andSoil Science Department, Michigan State University USA. https://msu.edu/ freed/mstatc.htm

[21] Shahzaman, M., M. Ishtiaq and A. Azam 2017. Effect of different fertilizers on seed germination and seedling growth of sunflower (Helianthus annuus L.) from district Bhimber of Azad Jammu and Kashmir, Pakistan. International Journal of Botany Studies. 2(2): 10-15.

http://www.botanyjournals.com/archives/2017/vol2/i ssue $2 / 2-1-28$

[22] Snedecor GW and WG. Cochran 1980. Statistical Methods. 7Th Ed. Iowa State University Press, Iowa, USA, ISBN-10: 0-81381560-6, Pp: 507. https://www.amazon.com/Statistical-MethodsSeventh-isbn-0813815606/dp/B0012S4NIE

[23]SSSA, 2011. Soil and Water Management and Conservation SSSA Division S-06, Annual Newsletter, October 2011 P6.https://dl.sciencesocieties.org/publications/aj/arti cles/109/3/739

[24] Songa, W., W. K. Ronno, and D. L. Danial 1994. Production constraints of beans in the semi-arid Eastern Kenya with special reference to charcoal rot," in Proceedings of the Regional Workshop for Eastern, Central and Southern Africa held at Njoro, Kenya, Wageningen Agricultural University, October 1994.pp. 251-255.

https://www.cabdirect.org/cabdirect/abstract/199516 10199

[25] Wambugu, P. W., P. W. Mathenge, E. O. Auma and H. A. vanRheenen (2012). Constraints to On-Farm Maize (Zea mays L.) Seed Production in Western 
Kenya: Plant Growth and Yield.International

Scholarly Research Network, ISRN Agronomy, Volume 2012, Article ID 153412, 7 pages. doi:10.5402/2012/153412

[26] Waller R.A. and B.D. Duncan 1969. A bays rule for the symmetric multiple comparison problem. J. Amer. Assoc., 64, 1484-1503. https://www.jstor.org/stable/2286085?seq=1\#page_s can_tab_contents

[27] Warraich EA, Basra SMA, Ahmad N, Ahmed R and Aftab M. 2002. Effect of nitrogen on grain quality and vigor in wheat (Triticum aestivum L.). International Journal of agriculture \& Biology 4:517-520.

http://www.fspublishers.org/published_papers/5383 _..pdf

[28] Yari, L., M. Aghaalikhani, and F. Khazaei, 2010. Effect of Seed priming duration and temperature on seed germination behavior of bread wheat (Triticum aestivum L.). ARPN Journal of Agriculture \& Biological Sciences, 5(1):16.http://www.arpnjournals.com/jabs/research_papers /rp_2010/jabs_0110_166.pdf

[29]Zakaria M.S., A. H. Fahmy and S. E. Yuosef 2007. Cotton Seed, Seed Viability and Seedling Vigour as Affected by Nitrogen, Potassium, Phosphorus, Zinc and a Plant Growth Retardant. The African Journal of Plant Science and Biotechnology, 1(1): 16-25. http://www.globalsciencebooks.info/Online/GSBOnl ine/images/0712/AJPSB_1(1)/AJPSB_1(1)16250.pdf

[30]Zakaria M.S., Ashraf HF and Serag EY. 2009. Direct and residual effects of nitrogen fertilization, foliar application of potassium and plant growth retardant on Egyptian cotton growth, seed yield, seed viability and seedling vigor. Acta Ecological Sinica, 29: 116-123. http://file.scirp.org/pdf/AS_2013122517125575.pdf 